\title{
Heberprot-P: \\ A Novel Product for Treating Advanced Diabetic Foot Ulcer
}

\author{
Jorge Berlanga DVM MS PhD, José I. Fernández MD, Ernesto López MS, Pedro A. López MD PhD, Amaurys del Río MD, \\ Carmen Valenzuela MS, Julio Baldomero MD, Verena Muzio MD PhD, Manuel Raíces PhD, Ricardo Silva PhD, \\ Boris E. Acevedo MD PhD, Luis Herrera MD PhD
}

\begin{abstract}
Diabetic foot ulcer is a principal diabetic complication. It has been shown that diabetic patients have decreased growth factor concentrations in their tissues, particularly epidermal growth factor. Growth factor shortage impairs wound healing, which leads to chronic nonhealing wounds and sometimes eventual amputation. Ischemic diabetic foot ulcer is the most difficult to treat and confers the highest amputation risk.
\end{abstract}

Injecting epidermal growth factor deep into the wound bottom and contours encourages a more effective pharmacodynamic response in terms of granulation tissue growth and wound closure. Epidermal growth factor injected into the ulcer matrix may also result in association with extracellular matrix proteins, thus enhancing cell proliferation and migration.

Heberprot-P is an innovative Cuban product containing recombinan human epidermal growth factor for peri- and intra-lesional infiltration; evidence reveals it accelerates healing of deep and complex ulcers, both ischemic and neuropathic, and reduces diabetes-related amputations.
Clinical trials of Heberprot-P in patients with diabetic foot ulcers have shown that repeated local infiltration of this product can enhance healing of chronic wounds safely and efficaciously. As a result, Heberprot$P$ was registered in Cuba in 2006, and in 2007 was included in the National Basic Medications List and approved for marketing. It has been registered in 15 other countries, enabling treatment of more than 100,000 patients.

Heberprot-P is a unique therapy for the most complicated and recalcitrant chronic wounds usually associated with high amputation risk. Local injection in complex diabetic wounds has demonstrated a favorable risk-benefit ratio by speeding healing, reducing recurrences and attenuating amputation risk. Further testing and deployment worldwide of Heberprot-P would provide an opportunity to assess the product's potential to address an important unmet medical need.

KEYWORDS Diabetic foot ulcer, Heberprot-P, amputation, healing, unmet medical need, rhEGF, Cuba

In 2007, treatment of DM and its complications in the USA generated some $\$ 116$ billion in direct and $\$ 58$ billion in indirect costs. [8] At least one third of direct costs were linked to DFU treatment. [9] There, estimated two-year followup costs for a DFU amputee range from $\$ 80,000$ to $\$ 110,000$.[10]

Antimicrobial agents, surgical techniques and a broad variety of therapeutic approaches based on drugs and devices have been applied to DFUs.[11-14] These interventions have shown limited clinical success, even when included in a comprehensive wound care program,[15] and there is no evidence of impact on amputation rates. Short-term recurrences remain a problem hampering clinical effectiveness of some contemporary therapies.[16]

Topical application of human growth factor dates back almost 30 years, when it sparked hopes of a 'magic bullet' for tissue healing. Two main factors quenched that initial excitement: the almost simultaneous finding from basic science that growth factors were involved in malignant growth[17] and disappointing results from a rigorous clinical trial in which EGF was topically administered to acute, experimentally-induced, controlled wounds in healthy volunteers.[18] The need to precondition the chronic wound bed and to ensure local growth factor bioavailability for subsequent receptor stimulation and downstream signaling activation emerged as paradigmatic concepts.[19,20]

\section{RATIONALE FOR GROWTH FACTOR WOUND INFILTRATION}

In Cuba, epithelial response to daily topical administration of three different EGF concentrations formulated in a semisolid cream was examined; results suggested a possible reduction of EGF bioavailability by proteases derived from noninfected, 
acute, controlled wounds.[21] This was somewhat surprising as other studies had already established proteolysis affecting growth factors and their receptors in chronic circumstances.[22,23] It is worth noting that previous studies had also documented the need for prolonged interaction between EGF and its receptor to achieve a significant granulation tissue response in controlled wounds in mice.[24] Our initial research indicated ${ }^{125}$ I-EGF was rapidly cleared from the application site, probably by protease-driven cleavage and receptor-mediated endocytosis. Mean residence time values suggested that over $60 \%$ of the amount administered could have disappeared as early as two hours after administration. [25] The message of these studies was that even acute, clean and controlled wounds may not represent a hospitable substrate for growth factor physical and chemical integrity. Previous disappointing clinical results may have been due to local bioavailability limitations.[26,27]

Such knowledge prompted the hypothesis that injecting EGF deep into the wound base and walls would allow for greater pharmacodynamic response in terms of granulation tissue growth and wound closure. In further studies, single or repeated EGF systemic or local injections produced clear-cut cytoprotective and proliferative responses, suggesting an intrinsic ability of EGF at supraphysiological concentrations to trigger biological events necessary for tissue repair.[28-30]

Injecting EGF into the tissue, down and inside the base and walls (including the dermo-epidermal junction), possibly also reduces its degradation following topical application and contact with wound exudate. These experiments identified three layers of cellular response potential along the longitudinal axis of granulation tissue. Fibroblasts populating the more superficial stratum expressed far more prohibitin and far less EGF receptor. Advanced glycosilated endproducts and elastase also appeared overexpressed next to the wound surface than in deeper cells strata. It is likely that topographic positioning along the wound bed axis dictates fibroblasts' intrinsic ability to respond to a mitogenic signal. Notably, prohibitin is a renowned inhibitor of cell cycle progression.[31] Contemporary evidence supports that EGF injected into the ulcer matrix may result in an association complex with extracellular matrix proteins, thus enhancing cell proliferation and migration.[32]

Classic studies have shown that growth factor effectively counteracts senescence of chronic ulcer-derived fibroblastsincluding diabetic ulcer fibroblasts-and stimulates proliferation.[33,34] Appropriate wound bed preparation through sharp debridement and infection elimination is required prior to infiltration.

\section{HEBERPROT-P IMPROVES HEALING AND REDUCES} AMPUTATIONS IN PATIENTS WITH SEVERE DFU

Following earlier research, scientists at the Center for Genetic Engineering and Biotechnology (CIGB, the Spanish acronym) in Havana developed Heberprot-P, a patented pharmaceutical composition whose parenteral formulation is based on rhEGF. The product is administered in DFU patients by intralesional infiltration to accelerate healing of deep and complex ulcers, either neuropathic or ischemic.[35]
Based on the rationale that rhEGF can enhance healing of chronic wounds following repeated local infiltrations,[36] various clinical trials using Heberprot-P in DFU patients have been conducted, demostrating safety and efficacy.[37-43] Infiltration with rhEGF for diabetic wound healing does not replace standard procedures but should be incorporated into comprehensive wound care along with medical interventions to correct patients' glycemia and creatinine.

In a compassionate study with terminal ulcer patients in 20012002, the first clinical evidence using EGF infiltration for diabetic foot ulcers and amputation residual bases emerged.[37] All lesions were chronic, complex and recalcitrant, Wagner scale stages 3 and 4.[36] Efficacy demonstrated in these types of wounds paved the way for solid clinical development, which culminated in a nationwide, double-blind, placebo-controlled phase III clinical trial, duly registered with the appropriate Cuban regulatory agency.[39]

Since then, EGF local injection has been used for complex diabetic wounds in various Cuban clinical trials, demonstrating a favorable risk-benefit balance by speeding healing, reducing recurrences and attenuating amputation risk.[43] Adverse effects were preponderantly mild to moderate $(65.6 \%$ mild, $28.6 \%$ moderate, and only $3.7 \%$ severe), with pain and burning sensation at administration site the most frequent. Pain reported was mild to moderate in intensity and was not associated with treatment suspension. A dose-effect relation associated with appearance of shivering and chills was consistently obtained in all trials at both doses used ( $25 \mu \mathrm{g}$ and $75 \mu \mathrm{g})$ and in the pooled analysis; intensity was mild to moderate and symptom appearance was not associated with treatment suspension.[39]

EGF infiltration increased and accelerated healing in poor-prognosis wounds toward a rapid and sustained response (Figure 1). More than $80 \%$ granulation was obtained globally with Heberprot$\mathrm{P}$, in comparison with less than $60 \%$ with standard care alone. Of patients treated with Heberprot-P at $75 \mu \mathrm{g}$, three times per week until complete granulation (or during 8 weeks) in association with standard care, $77 \%$ healed; while only $56 \%$ healed with placebo injections and standard care.[40] Seminal clinical trials are summarized in Table 1.

As a result, Heberprot-P was registered in Cuba in 2006, and in 2007 was included in the National Basic Medications List and approved for marketing. Heberprot- $P$ has also been registered in 15 other countries (Table 2) enabling treatment of over 100,000 patients. Registration and market approval submissions are in process in countries such as Brazil, Russia, China, South Africa, and the Arab states of the Persian Gulf. A Spanish phase II clinical trial for the DFU indication, approved by the Spanish Drug Agency under European Good Clinical Practices, concluded recently (publication pending), with the aim of moving to a pivotal phase III clinical trial in Europe.

\section{EFFECTIVE COMPREHENSIVE DFU TREATMENT:}

\section{AN UNMET MEDICAL NEED}

Adjuvant therapies and advanced technologies can be used in addition to standard care as a second line of treatment when appropriate. These include some topical drugs but are mostly medical devices: living skin equivalents, specialized dressings, hyperbaric oxygen therapy and negative pressure devices. These interventions provide moderate improvement over standard treat- 
Figure 1: Severe diabetic foot ulcers treated with Heberprot-P

\section{Ischemic Patient A}

Before first injection of Heberprot-P: $11.9 \mathrm{~cm}^{2}$

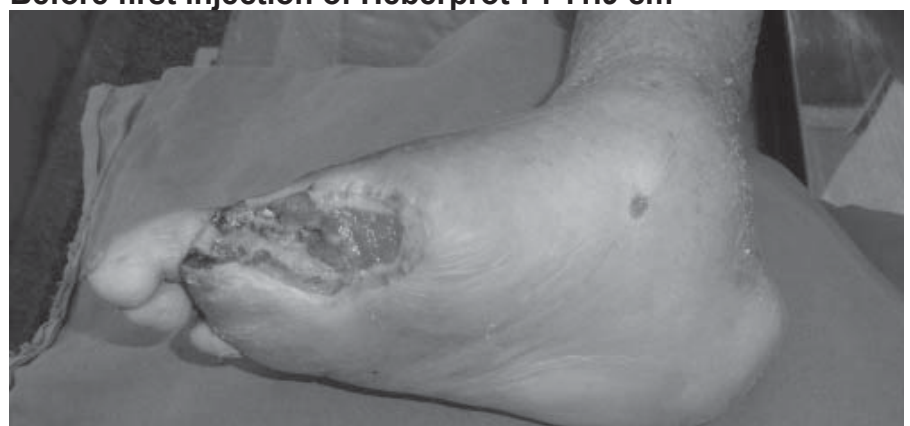

After seven weeks' treatment: $1.1 \mathrm{~cm}^{2}$

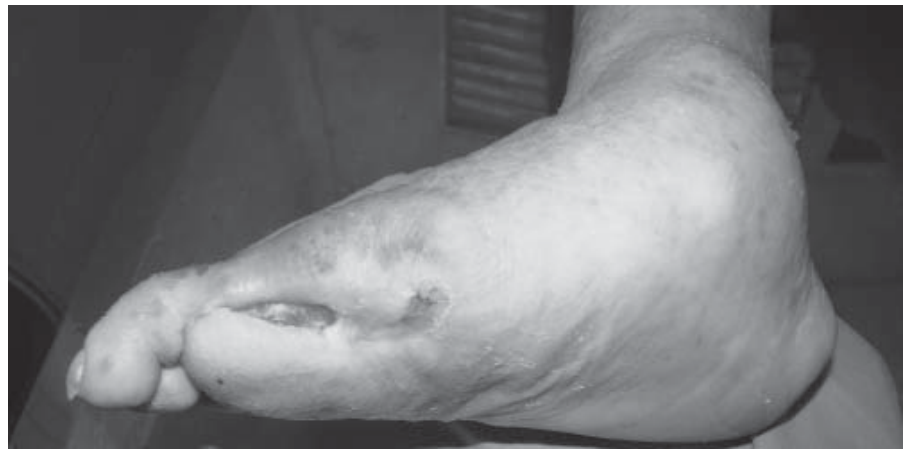

\section{At week 11: healed}

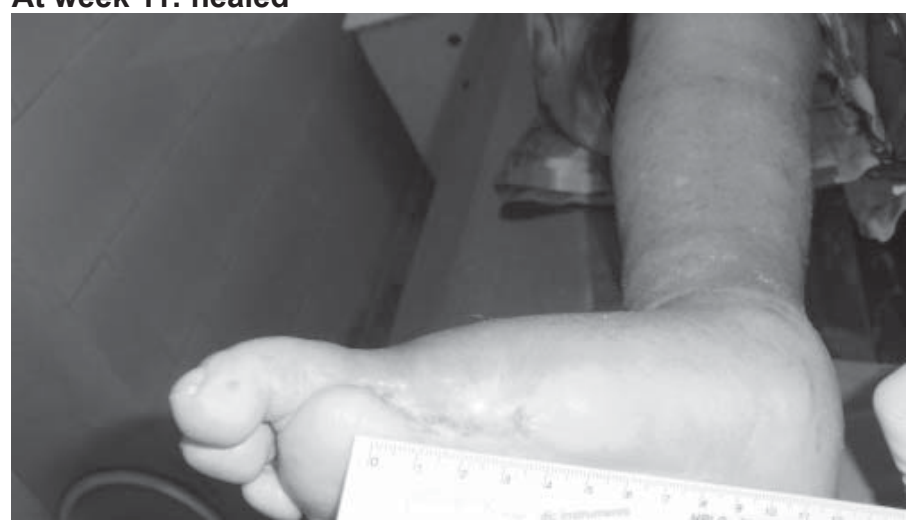

Photos: Dr A del Río Martín

(available in color online at www.medicc.org/mediccreview/berlanga.html)

\section{Ischemic Patient B}

Before first injection of Heberprot-P: $21.8 \mathrm{~cm}^{2}$

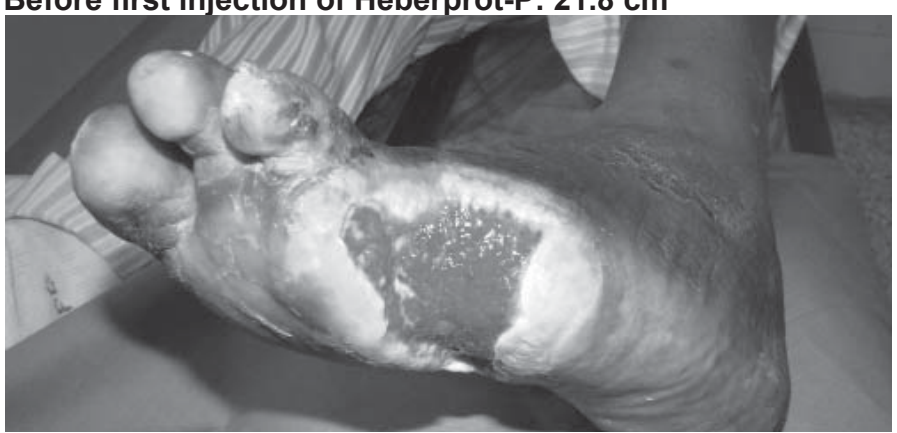

After seven weeks' treatment: $0.5 \mathrm{~cm}^{2}$

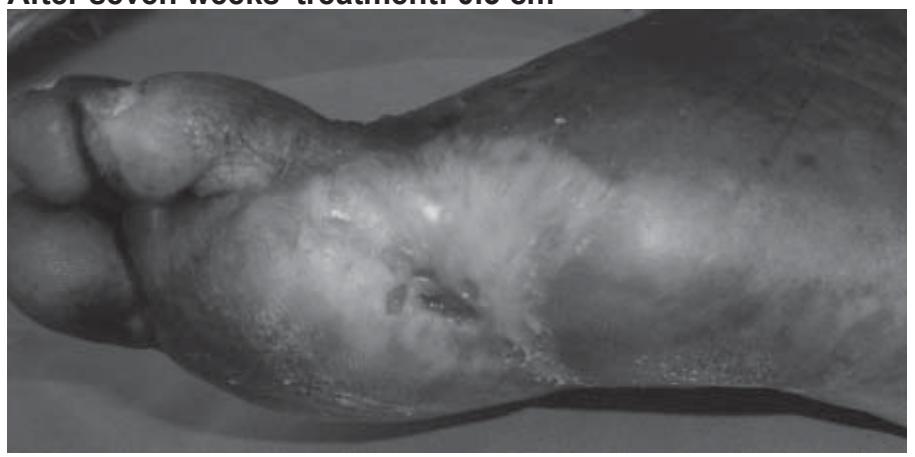

\section{At week 11: healed}

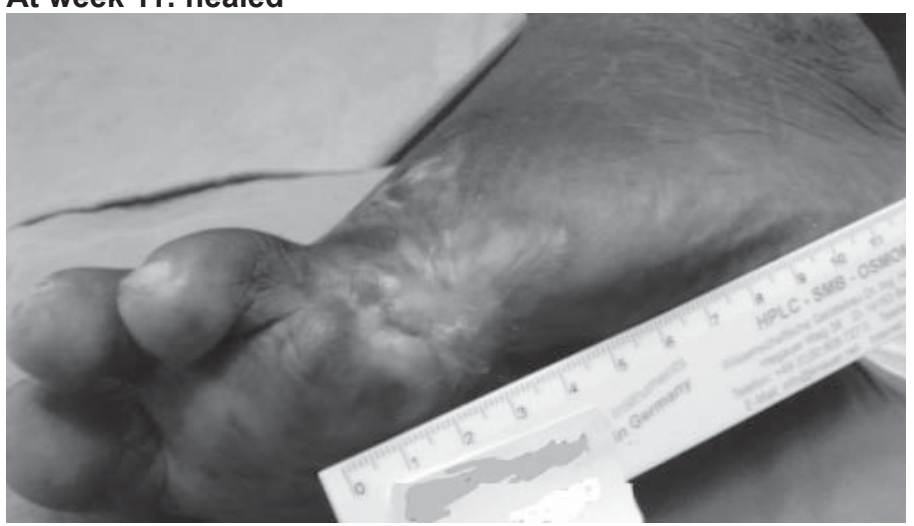

Table 1: Seminal clinical trials with Heberprot-P

\begin{tabular}{|c|c|c|c|}
\hline Trial & Details & Results & Ref. \\
\hline Phase I: Exploratory & $\begin{array}{l}\text { Patients with poor prognosis, } 25 \mu \mathrm{g} \text { three times a week, } \\
\text { until granulation or } 8 \text { weeks }\end{array}$ & $\begin{array}{l}\text { Good safety pattern } \\
\text { Promising results in granulation, healing and } \\
\text { amputation avoidance }\end{array}$ & 37 \\
\hline $\begin{array}{l}\text { Phase II: Treatment } \\
\text { dose determination }\end{array}$ & $\begin{array}{l}25 \mu \mathrm{g} \text { or } 75 \mu \mathrm{g} \text { three times a week, until granulation or } \\
8 \text { weeks }\end{array}$ & $\begin{array}{l}\text { Good safety pattern in both doses } \\
\text { Trend to greater efficacy at } 75 \mu \mathrm{g}\end{array}$ & 38 \\
\hline $\begin{array}{l}\text { Phase II: Treatment } \\
\text { dose determination }\end{array}$ & $\begin{array}{l}25 \mu \mathrm{g} \text { or } 75 \mu \mathrm{g} \text { three times a week, until healing or } 8 \\
\text { weeks }\end{array}$ & $\begin{array}{l}\text { Trend to greater efficacy when treatment is } \\
\text { prolonged until healing }\end{array}$ & 39 \\
\hline $\begin{array}{l}\text { Phase III: Confirmatory } \\
\text { trial }\end{array}$ & $\begin{array}{l}\text { Double-blind placebo-controlled multicenter study, } 25 \\
\mu \mathrm{g} \text { versus } 75 \mu \mathrm{g} \text { versus placebo (all } 3 \text { times a week) }\end{array}$ & $\begin{array}{l}\text { Confirm efficacy (granulation and healing) and } \\
\text { safety in patients with Wagner 3-4 DFUs }\end{array}$ & 40 \\
\hline $\begin{array}{l}\text { Phase IV: } \\
\text { Pharmacovigilance }\end{array}$ & Pharmacovigilance study in 1835 patients & Confirmation of safety profile & Unpublished \\
\hline
\end{tabular}

DFU: diabetic foot ulcer 
ments, generally only $15 \%$ to $20 \%$ healing in less than 20 weeks, and may be expensive and time consuming.[44] In ischemic patients, surgical revascularization is not suitable for all cases and

Table 2: Heberprot-P registration year by country Country Registration Year

Cuba

Algeria 2008

Argentina 2009

Uruguay 2009

Dominican Republic

2009

Venezuela

2010

Ecuador

2010

Mexico

2010

Paraguay

2010

Libya 2010

Colombia

Guatemala

2011

Georgia

2011

Ukraine

2011

2011

Vietnam

2012

Philippines some authors consider its effectiveness to be overestimated:[45] in any case, the regulatory process for surgical procedures does not require the same degree of clinical detail as demanded for biological products. There remains a clear need for adequate comprehensive therapy to improve healing in severe wounds, for which Heberprot-P has demonstrated clear beneficial potential.

In the USA, $8.3 \%$ of the population-25.8 million people-have DM,[46] and therefore an estimated $25 \%$ lifetime risk of developing a DFU.[47] The International Diabetes Federation predicts that the number of people with DM in the USA will be 36 million in 2030, $12 \%$ population prevalence.[48]

The estimated number of US DFU patients in 2010 was between 3.9 and 4.6 million. Among these, 2.5 million patients had concomitant ischemia and hence were at greater risk of complications.[49] Heberprot-P would address the therapeutic needs of this population, as well as those at risk globally, especially patients with ischemic wounds that are the most difficult to heal.

Further testing of Heberprot-P $-\mathrm{a}$ unique and first-in-class therapy to treat the most complicated and recalcitrant chronic wounds with a high risk of amputation- would provide an opportunity to assess the product's potential to address this vast unmet medical need in different populations and settings worldwide.

\section{REFERENCES}

1. Davis WA, Norman PE, Bruce DG, Davis TM. Predictors, consequences and cost of diabetesrelated lower extremity amputation complicating type 2 diabetes: the Fremantle Diabetes Study. Diabetologia. 2006 Nov;49(11):2634-41.

2. Berlanga J, Schultz G, Lopez P. Biology of the diabetic wound. In: Overhaussen PE, editor. Foot ulcers: causes, diagnosis and treatments. New York: Nova Science Publishers, Inc.; 2009.

3. Schultz G, Berlanga J, Cowan L, Stechmiller J. Linking the advanced glycation endproducts/ receptor for advanced glycation endproduts pathway in diabetics with inflammation and topical antiinflammatory treatments of chronic wound. In: Chandan S, editor. Advances in Wound Care. Columbus (US): Ohio State University Medical Center; 2009. Chapter 44. Vol 1.

4. CDC Online Press Release [Internet]. Atlanta: Center for Disease Control and Prevention (US); [reviewed 2012 Nov 12; cited 2012 Sep 18]. Available from: www.cdc.gov/diabetes/

5. Li Y, Burrows NR, Gregg EW, Albright A, Geiss LS. Declining rates of hospitalization for nontraumatic lower-extremity amputation in the diabetic population aged 40 years or older: U.S., 19882008. Diabetes Care. 2012 Feb;35(2):273-7.

6. International Working Group on the Diabetic Foot [Internet]. Brussels: International Diabetes Federation; c2000-2005. Foot Note Brazil; [cited 2012 Nov 5]; [about 1 screen]. Available from: http://www.iwgdf.org/ index.php? Itemid=37\&id=10\&option $=$ com content\&task=view

7. Anuario Estadístico de Salud 2010. Havana: Ministry of Public Health (CU); 2011 Apr. Spanish.

8. American Diabetes Association. Economic costs of diabetes in the U.S. in 2007. Diabetes Care. 2008 Mar;31(3):596-615.

9. Driver VR, Fabbi M, Lavery LA, Gibbons G. The costs of diabetic foot: the economic case for the limb salvage team. J Am Podiatr Med Assoc. 2010 Sep-Oct;100(5):335-41.
10. Carls GS, Gibson TB, Driver VR, Wrobel JS, Garoufalis MG, Defrancis RR, et al. The economic value of specialized lower-extremity medical care by podiatric physicians in the treatment of diabetic foot ulcers. J Am Podiatr Med Assoc. 2011 Mar-Apr;101(2):93-115.

11. Wieman TJ, Smiell JM, Su Y. Efficacy and safety of a topical gel formulation of recombinant human platelet-derived growth factor-BB (becaplermin) in patients with chronic neuropathic diabetic ulcers. A phase III randomized placebo-controlled double-blind study. Diabetes Care. 1998 May;21(5):822-7.

12. Armstrong DG, Lipsky BA. Diabetic foot infections: stepwise medical and surgical management. Int Wound J. 2004 Jun;1(2):123-32.

13. Dalla PL, Faglia E. Treatment of diabetic foot ulcer: an overview strategies for clinical approach. Curr Diabetes Rev. 2006 Nov;2(4):431-47.

14. Ha Van G. [Management of a diabetic foot ulcer]. Rev Med Interne. 2008 Sep;29 Suppl 2:S238S42. French.

15. Smiell JM, Wieman TJ, Steed DL, Perry BH, Sampson AR, Schwab BH. Efficacy and safety of becaplermin (recombinant human platelet-derived growth factor-BB) in patients with nonhealing, lower extremity diabetic ulcers: a combined analysis of four randomized studies. Wound Repair Regen. 1999 Sep-Oct;7(5):335-46.

16. Gregor S, Maegele M, Sauerland S, Krahn JF, Peinemann F, Lange S. Negative pressure wound therapy: a vacuum of evidence? Arch Surg. 2008 Feb;143(2):189-96.

17. Berlanga-Acosta J, Gavilondo J, García del Barco D, Martín J, Guillén G. Epidermal Growth Factor (EGF) and Platelet-Derived Growth Factor (PDGF) as tissue healing agents: Clarifying concerns about their possible role in malignant transformation and tumor progression. J Carcinogene Mutagene. 2011 Feb 25;2(1):100-15.

18. Cohen IK, Crossland MC, Garrett A, Diegelmann RF. Topical application of epidermal growth factor onto partial-thickness wounds in human volunteers does not enhance reepithelialization. Plast Reconstr Surg. 1995 Aug;96(2):251-4.

19. Schultz GS, Sibbald RG, Falanga V, Ayello EA, Dowsett C, Harding K, et al. Wound bed preparation: a systematic approach to wound management. Wound Repair Regen. 2003 Mar;11 Suppl 1:S1-28.

20. Sibbald RG, Orsted H, Schultz GS, Coutts P, Keast D; International Wound Bed Preparation Advisory Board. Preparing the wound bed 2003: focus on infection and inflammation. Ostomy Wound Manage. 2003 Nov;49(11):23-51.

21. Berlanga J, Lodos J, Reyes O, Caballero E, Lopez Saura P. Epidermal growth factor stimulated re-epithelialization in pigs. The possible role of acute wound proteases. Biotecnol Aplicada. 1998;15(2):83-7.

22. Saarialho-Kere UK. Patterns of matrix metalloproteinase and TIMP expression in chronic ulcers. Arch Dermatol Res. 1998 Jul;290 Suppl:S47-54.

23. Mast BA, Schultz GS. Interactions of cytokines, growth factors, and proteases in acute and chronic wounds. Wound Repair Regen. 1996 Oct;4(4):411-20.

24. Buckley A, Davidson JM, Kamerath CD, Wolt TB, Woodward SC. Sustained release of epidermal growth factor accelerates wound repair. Proc Natl Acad Sci USA. 1985 Nov;82(21):7340-4.

25. Prats PA, Duconge J, Valenzuela C, Berlanga $J$, Edrosa CR, Fernández-Sánchez E. Disposition and receptor-site binding of (125)I-EGF after topical administration to skin wounds. Biopharm Drug Dispos. 2002 Mar;23(2):67-76.

26. Falanga $\mathrm{V}$, Eaglstein $\mathrm{WH}$, Bucalo $\mathrm{B}$, Katz $\mathrm{MH}$, Harris B, Carson P. Topical use of human recombinant epidermal growth factor (h-EGF) in venous ulcers. J Dermatol Surg Oncol. 1992 Jul;18(7):604-6.

27. Falanga V. Growth factors and chronic wounds: the need to understand the microenvironment. J Dermatol. 1992 Nov;19(11):667-72. 
28. Berlanga-Acosta J, Gavilondo-Cowley J, LópezSaura P, González-López T, Castro-Santana MD, López-Mola E, et al. Epidermal growth factor in clinical practice - a review of its biological actions, clinical indications and safety implications. Int Wound J. 2009 Oct;6(5):331-46.

29. Berlanga J, Caballero E, Prats P, López Saura $\mathrm{P}$, Playford RJ. [The role of the epidermal growth factor in cell and tissue protection]. Med Clin (Barc). 1999 Sep 4;113(6):222-9. Spanish.

30. Berlanga-Acosta J, Playford RJ, Mandir N, Goodlad RA. Gastrointestinal cell proliferation and crypt fission are separate but complementary means of increasing tissue mass following infusion of epidermal growth factor in rats. Gut. 2001 Jun;48(6):803-7.

31. Mishra S, Murphy LC, Nyomba BL, Murphy LJ. Prohibitin: a potential target for new therapeutics. Trends Mol Med. 2005 Apr;11(4):192-7.

32. Hollier B, Harkin DG, Leavesley D, Upton Z. Responses of keratinocytes to substrate-bound vitronectin: growth factor complexes. Exp Cell Res. 2005 Apr 15;305(1):221-32.

33. Stanley AC, Park HY, Phillips TJ, Russakovsky $\mathrm{V}$, Menzoian JO. Reduced growth of dermal fibroblasts from chronic venous ulcers can be stimulated with growth factors. J Vasc Surg. 1997 Dec;26(6):994-9.

34. Loots MA, Lamme EN, Mekkes JR, Bos JD, Middelkoop E. Cultured fibroblasts from chronic diabetic wounds on the lower extremity (noninsulin-dependent diabetes mellitus) show disturbed proliferation. Arch Dermatol Res. 1999 Feb-Mar;291(2-3):93-9.

35. Berlanga J, Fernández JI, Valdés C, Franco N, Rojas I, Santana H, et al, inventors; Centro de Ingeniería Genética Biotechnología, assignee. Use of a pharmaceutical composition containing epidermal growth factor (EGF) for diabetic foot amputation prevention. World patent WO PCT/ CU2002/000011. 2008 Dec 18.

36. Berlanga-Acosta J. Diabetic lower extremity wounds: the rationale for growth factorsbased infiltration treatment. Int Wound J. 2011 Dec;8(6):612-20.

37. Acosta JB, Savigne W, Valdez C, Franco N, Alba JS, del Río A, et al. Epidermal growth factor intralesional infiltrations can prevent amputation in patients with advanced diabetic foot wounds. Int Wound J. 2006 Sep;3(3):232-9.

38. Fernández-Montequín Jl, Infante-Cristiá $\mathrm{E}$, Valenzuela-Silva C, Franco-Pérez N, SavigneGutierrez W, Artaza-Sanz H, et al. Intralesional injections of Citoprot $P \circledast$ (recombinant human epidermal growth factor) in advanced diabetic foot ulcers with risk of amputation. Int Wound J. 2007 Dec;4(4):333-43.
39. Fernández-Montequín JI, Betancourt BY, LeyvaGonzalez G, López Mola E, Galán-Naranjo K Ramírez-Navas M, et al. Intralesional administration of epidermal growth factor-based formulation (Heberprot-P) in advanced diabetic foot ulcer: Treatment up to complete wound closure. Int Wound J. 2009 Feb;6(1):67-72

40. Fernández-Montequín J, Valenzuela-Silva CM González-Díaz O, Savigne W, Sancho-Soutelo $N$, Rivero-Fernández $F$, et al. Intra-lesional injections of recombinant human Epidermal growth factor promote granulation and healing in advanced diabetic foot ulcers. Multicenter, randomized, placebo-controlled, double blind study. Int Wound J. 2009 Dec;6(6):432-43.

41. Hernández Rivero MJ, Llanes Barrios JA, Acosta Lapera DS. [Heberprot-P, an effective therapy for prevention of diabetic foot amputation]. Rev Cubana Angiol Cirugía Vascular. 2009;10(1):311. Spanish.

42. Valenzuela-Silva CM, Tuero-Iglesias AD, GarcíaIglesias E, González-Díaz O, del Río-Martín A, Yera-Alos IB, et al. Granulation Response and Partial Wound Closure predict Healing in Clinical Trials on Advanced Diabetes Foot Ulcers Treated with Recombinant, Human Epiderma Growth Factor. Diabetes Care. 2012 Sep 10 [Epub ahead of print]

43. López-Saura PA, Berlanga-Acosta J, FernándezMontequín JI, Valenzuela-Silva C, González-Díaz $\mathrm{O}$, Savigne W, et al. Intralesional Human Recombinant Epidermal Growth Factor for the Treatment of Advanced Diabetic Foot Ulcer: From Proof of Concept to Confirmation of the Efficacy and Safety of the Procedure. In: Dinh T, editor. Global Perspective on Diabetic Foot Ulcerations. Rijeka (HR): InTech; 2011 Dec 9. 278 p.

44. Blume P, Driver VR, Tallis AJ, Kirsner RS, Kroeker R, Payne WG, et al. Formulated collagen gel accelerates healing rate immediately after application in patients with diabetic neuropathic foot ulcers. Wound Repair Regen. 2011 MayJun;19(3):302-8.

45. Taylor SM, Johnson BL, Samies NL, Rawlinson RD, Williamson LE, Davis SA, et al. Contemporary management of diabetic neuropathic foo ulceration: a study of 917 consecutively treated limbs. J Am Coll Surg. 2011 Apr;212(4):532-45.

46. CDC [Internet]. Atlanta (US): Center for Disease Control and Prevention (US); 2012. 2011 National Diabetes Fact Sheet; [updated 2012 Jan; cited 2012 Sep]; [2.7 MB]. Available from: www.cdc .gov/diabetes/pubs/pdf/ndfs_2011.pdf

47. Singh N, Armstrong DG, Lipsky BA. Preventing foot ulcers in patients with diabetes. JAMA. 2005 Jan 12;293(2):217-28.

48. International Diabetes Federation. IDF Diabetes Atlas, 4th ed. Brussels (BE): International Diabetes Federation; 2007.
49. Yost ML. Diabetic Foot Ulcers, peripheral artery disease and critical limb ischemia, 2010. Atlanta, Georgia: The SAGE Group; 2010.

\section{THE AUTHORS}

Jorge Berlanga Acosta, veterinarian with a master's degree in pathology and a doctorate in pharmacology, Center for Genetic Engineering and Biotechnology (CIGB), Havana, Cuba.

José I. Fernández Montequín, angiologist and vascular surgeon, National Institute for Angiology and Vascular Surgery, Havana, Cuba.

Ernesto López Mola, nutritional pharmacist with a master's degree in biotechnology, CIGB, Havana, Cuba.

Pedro A. López Saura, clinical biochemist with a doctorate in biology, CIGB, Havana, Cuba

Amaurys del Río Martín, medical immunologist, CIGB, Havana, Cuba.

Carmen Valenzuela Silva, mathematician, CIGB.

Julio Baldomero Hernández, family physician, CIGB, Havana, Cuba.

Verena Muzio González, immunologist with a doctorate in biology, CIGB, Havana, Cuba.

Manuel Raíces Pérez, biologist. Business and Projects Development Division, CIGB, Havana, Cuba.

Ricardo Silva Rodríguez, biologist, CIGB, Havana, Cuba.

Boris E. Acevedo-Castro (Corresponding author: boris.acevedo@cigb.edu.cu), physician with a doctorate in medical sciences, CIGB, Havana, Cuba.

Luis Herrera Martínez, geneticist with a doctorate in biology. Director General, CIGB, Havana, Cuba.

Submitted: September 14, 2012

Approved for publication: January 15, 2013

Disclosures: All authors except Fernández are employed at CIGB, developer of Heberprot-P 